\title{
DEVELOPING ENGLISH LEARNING MATERIAL FOR SPEAKING SKILL BASED ON PROBLEM -BASED LEARNING (PBL) AT FIRST SEMESTER OF THE EIGHTH GRADE OF JUNIOR HIGH SCHOOL
}

\author{
Hidha Fajarwati \\ Amirudin Latif \\ English Education Study Program, Teacher Training and Education Faculty, \\ Muhammadiyah University of Metro
}

\begin{abstract}
The objective of the study is to develop practical English speaking materials by using Problem Based Learning (PBL). The design of the study is research and development which attempts to develop descriptive and recount text for speaking materials. The steps of the research and development for the materials include self evaluation, expert review, one-to-one try out, small group try out, field test, and final product. The subjects of this research are the eighth grade students of State Junior High School 6 Metro. The result of the study is English learning material for speaking skill based on problem based learning.
\end{abstract}

Keywords: Learning material, speaking, problem-based learning

Education is one of the important factors in this life. Education is a way that must be done by the people to get knowledge. It brings people to get a better life and it can measure the attitude that people have. For most conditions, those who have better education will behave better.

English is one of the international languages used by most of people in the world. As a part of education in this globalization era, English plays a prominent role in the world. Most of sources of information including book, science, and technology are written in English. Meanwhile, in Indonesia, English is a foreign language. Actually English has been introduced to educational institutions which are learnt from elementary school up to university level as an important subject to be learned. To be able to communicate, good English skill is needed. These skill includes of listening, speaking, reading, and writing. One of the four English skills is speaking. It is an important skill which must be mastered. Sometimes spoken language is easy to perform, but in some it is difficult (Brown, 2001: 270). It means in speaking we should master vocabulary and grammar, so we can produce every single words that what we are going to say.

Learning English, students are expected to communicate the ideas, opinion and express their feeling. By speaking, someone will understand what the meaning is. In this case, students who have learned English are not successful in speaking. It means that most of the students cannot get some information from the speaking materials given easily and it will be very difficult for them to understand it.

In teaching and learning English, it also depends on learning materials. Learning materials are usually the assignments that the student has to do. It is to practice and improve their knowledge. Teachers need to understand and develop the materials in order to get students understanding. Problem Based Learning (PBL) is an approach recommended in developing material. Boud and Felleti (1991) state that Problem Based Learning is a way of constructing and teaching course using problem as a stimulus and focus on student activity. In Problem Based Learning students learn to be self- 
directed, independent and interdependent learners motivated to solve a problem. Initially the students explore the problem using their prior knowledge and experience. They then analyse the problem and formulate hypotheses that might explain the problem. They use this information to determine the further information they require to understand and solve the problem.

PBL encourages students to learn through the structured exploration of a research problem and to take responsibility for their own learning by providing a problem that needs solving. Students are developing knowledge within a context, and also developing skills in deploying their new knowledge.

Realizing how important of speaking and all the difficulties in learning speaking, the researcher want to develop English learning materials for teaching speaking skill using Problem Based learning (PBL) for students of eighth grade of Junior High School.

\section{LITERATURE REVIEWS}

\section{Concept of Speaking Skill}

Brown (2001: 267) state that when someone can speak a language, it means that he can carry on a conversation reasonably competently. He states that the benchmark of successful acquisition of language is almost always the demonstration of an ability to accomplish pragmatic goals through an interactive discourse with other language. Fulcher gives the wide explanation that is summarized into three factor in speaking namely:

\section{a. Pronunciation}

A way in which languages in spoken English in the definition of pronunciation it is included of segmental feature, vowel, consonant, stress and the intonation pattern. The speakers are supposed to apply them oral and correctly. Harmey says that native speaker or competent users of the language know to say a word that is how pronouncing it. $\mathrm{He}$ adds the pronunciation knowledge made up the three areas, sound, stress, and intonation.

\section{b. Vocabularies}

One of the linguistic factors in which it is a number of words with the role combining to make up language in speaking. Vocabulary is very essential but it is not the first thing to be described if speaking take place in a very early stages. Vocabulary is the total number of words which make up a language.

\section{c. Fluency}

It shows that people are able to communicate well because it consist of the ease and speed of the flow speech. Someone can be said fluent if he can require some criteria of categories to say the words fluently and know what we will say then.

The concept of speaking according of oxford learner's pocket dictionary (2003:414), the meaning of speaking is; talk to somebody; use your voice to say something. Speaking is an important aspect in language learning. By speaking, we can convey information and ideas, and maintain social relationship by communicating with others. In addition, a large percentage of the world's language learners study English in order to be able to communicate fluently. Speaking is one of skills in English which important to be mastered.

Tarigan in Sholihin (1990: 3-4) defines that speaking is a language skill that is developed in child life, which is produce by listening skill, and at that period speaking skill is learned. Most people might spend their everyday life in communicating with others. The communication consists of ideas, opinions and feeling. Therefore, communication 
involves at least two people where both sender and receiver need to communicate to exchange information, ideas, opinions, views, or feelings.

Based on the explanation above, it can be concluded that speaking is the important skill in English to communicate with others. The speaker should speak fluently, so the listener can understand what they mean and know what they will say then. Here, the speaker must consider fluency, intonation, pronunciation, and others.

\section{Concept of Teaching Speaking skill}

Speaking is an important aspect in life. By speaking, the speaker can communicate with others and use language to send message. According to Hornby (1995:37) teaching means giving instruction or knowledge to a person. While speaking means to make use of words in an ordinary voice, teaching speaking is giving instruction to a person in order to communicate.

Speaking is a language skill that is developed in life, which is preceded by listening skill and at the period speaking skill is learned. It means that speaking is the basic language. Teaching speaking skills is to communicate efficiency. Learners should be able to make themselves understood by using their current proficiency to the fullest. The learner have to try to avoid confusion in the message due to faulty on pronunciation, grammar or vocabulary and to observe the social and natural rules that applied in each communication situation.

Based on the explanation above, it can be conclude that speaking is the way for students to express their emotion, communicative needs, interact to other person in some situations. For this reason, it have to clear understanding involved in speech.

\section{Concept of Learning Material}

Most of people consider that the term of 'language-learning materials' are course book. However, the languagelearning materials are more than it. Materials are a set of product used in language teaching and learning. Materials can be in the form of newspapers, workbooks, photocopied exercises, etc. Tomlinson (1998: 2), state "Materials refer to anything which is used by the teachers or learners to facilitate the learning of a language that is able to improve the students' knowledge and experience of the language". Materials are important element within the curriculum and the most tangible and visible aspect of it. It means that materials generally serve as the basis for much of the language input that learners receive and the language practice that occurs in the classroom.

It can be concluded that materials are important element which is used by teacher or learners in learning process to improve their language knowledge and it can be in form of newspapers, workbooks, photo copied exercise.

\section{The role of materials}

Materials are used in all teaching to support the success of learning process. Not only materials used by teacher but also audio and video cassettes, overhead transparancies, computer and other equipment or real objects. It means that materials play an important role in teaching learning process, especially in teaching English. There are four important roles of materials in the ESP context proposed by Dudley-Evans and St. John (1998:170-172):

\section{1) Source of language}

In some situations, where English is a foreign language, ESP classroom may be the only source of English. Materials then 
play a crucial role in exposing learners to the language; it means that materials need to present real language. Where the classroom is the primary source of language, the materials also need to maximize exposure to the language by providing additional materials.

\section{2) Learning Support}

As a learning support, materials need to be reliable, that is, to be consistent and have some recognizable patterns. To enhance learning, materials must involve learners in thinking about and using the language. The activities need to stimulate cognitive not mechanical process. The learners also need a sense of progression.

\section{3) Stimulation and motivation}

To stimulate and motivate, materials need to be challenging to offer new ideas and information, to encourage fun and creativity. The input must contain the concepts and knowledge that are familiar but it must also offer something new, a reason to communicate, to get involve.

\section{4) Reference}

For self-study or reference, materials need to be complete, well laid out and self explanatory. The learners will want explanations, examples and practice activities that have answer and discussion keys.

In short, materials are one of the important things to support the learning process. The materials that facilitate language learning are the materials that are used typically with the subject matter of the content course. There are some important roles of material such as source language, learning support, stimulation and motivation and reference.

Based on the statement above, it can conclude that effective learning materials is needed by the learners to develop their confidence, to use the language effectively, to facilitate learners in learning process and give learners opportunities to use the language. In developing effective learning materials, there are many aspects that should be considered, such as criteria of effective learning.

\section{Concept of Problem Based Learning (PBL)}

Problem based learning is one of those pedagogic phenomenon that is both a learning activity and an assessment. Problem based learning is a student centred learning strategy in which learners confront contextualised, ill-structured problems similar to real world situations. PBL guides learners to discover the knowledge themselves by confronting the problem and activates their prior knowledge with very little initial content knowledge given; it encourages deep learning as well as learners to be responsible for their own learning. Margetson (2001) provides convincing philosophical arguments for the rationale for learning in higher education to be based on problem.

In PBL the problem is not defined narrowly as something broken that need to be fixed but wider as an-ill defined, challenging starting point for learning. In problem-based learning, the problem is presented first after which students work in small teams to solve the problem. PBL is any learning environment in which the problem drives the learning. That is, before students learn some knowledge they are given a problem. The problem is posed so that the students discover that they need to learn some new knowledge before they can solve the problem.

Based on the explanation above, it can be concluded that problem based learning guides learners to discover the knowledge, and the problem is presented first after which students work in small teams to solve the problem. 


\section{METHOD}

The type of research that is conducted by the writer is developmental research. The research is not meant to generate a theory or verify one. It attempts to develop English learning material for speaking skill based on Problem Based Learning (PBL).

In this research, the researcher uses formative research research design proposed by Tessmer (1993). Two kinds of text are developed in this research namely descriptive and recount text. The development steps of material are below:

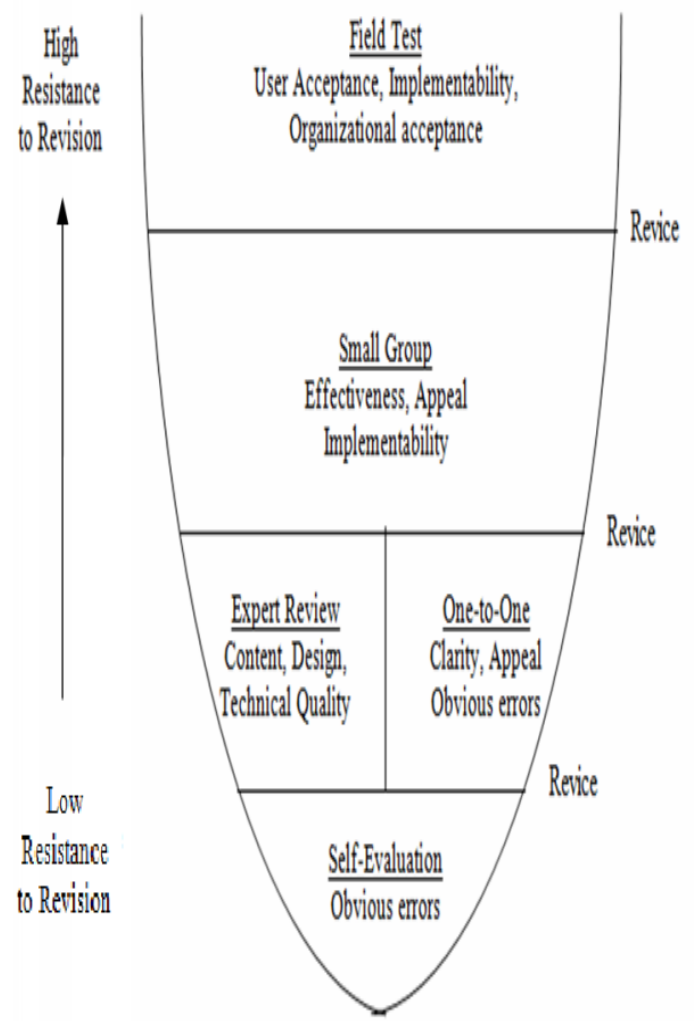

Based on instructional design flowchart, it produces a proto-type (initial product) form. In the description on the development steps of material as follows:

\section{Self Evaluation}

The researcher wants to develop a material for speaking skill and reveal the concept of Problem Based Learning. It is also intended for students in junior high school especially.

In this step, designing the material for speaking skill for recount and descriptive text are the main things. The researcher develops based on the analyzing and main competence in curriculum 2013. The first design called first prototype.

This research produces some prototypes, such as first prototype (the result of self evaluation), second prototype (revision and expert review and one-toone) and the third prototype is the last prototype (revision in small group), and each of prototypes are focusing on: language, readability, and implementability.

\section{Expert Review}

In this part, the first prototype is observed, evaluated and rated by the experts or panelists. The experts or panelists consist of two experts in English instruction studies. All of the panelists analyze language, readability, and implement ability. The suggestion from the panelist is used to revise the first prototype.

\section{One-to-one}

From this step the researcher utilizes two students as the testier and ask them to observe and give the comment about English speaking material. The testier are the students at eighth grade of State Junior High School 6 Metro. The purpose of oneto-one step is to identify gross problems on material product. The result from this step is used to revise the material product.

The result of expert review and oneto-one are important things to renew the 
first prototype. And it will produce the second prototype.

\section{Small Group}

The researcher has applied revision, the second prototypes is given to six students as non subject research. Every student completes and gives comment the product which has been revised based on expert judgement and one-to-one (second prototype). The result of this stage is revised to be the third prototype (product).

The purpose of the small group step is to determine whether the product has been suitable or not. This step is conducted in one class of eighth grade of State Junior High School 6 Metro. All of respondents are taken by simple random technique. Each of respondents get the product and finish it. After giving the product, the students have to answer the questions of questionnaires to know readability and implementability. Then, the researcher revises it as the third prototype.

\section{Field Test}

The researcher conducts a field test to get standard product. In this step, the reseacher only focuses on the improvement and the effectiveness of the product, not pay attention in viability the context of population.

The reseacher analyzes the data by using the of questionaire of readability and implementability of the product. This stage is conducted one class of the eighth grade in State of Junior High School 6 Metro and involves twenty five respondents. The respondent is gotten randomly. The respondents are given the material of the product based on PBL development, after that the respondents are given questionnaires to know readability and implementability of the product of English learning material for speaking skill based on PBL development.
The result of questionnaires from the respondents is discussed by researcher. The result of this stage becomes final product.

\section{Research Method: Stage 1}

\section{Product Design}

This prototype is designed based on Problem Based Learning especially for speaking skill. It is gotten by self evaluation, expert review and one to one, small group and field test. In small group, the researcher gets the result and it is revised for the second product. The result is the third prototype.

\section{Research Subject}

The subjects of this research are the student of State Junior High School 6 Metro at eighth grade. It is gotten by simple random sampling. After getting six respondents, they get the second prototype (from expert judgments and one-to-one) and they get questionnaire of readability and implementability of the product. The respondents are asked to give comments related to product based on PBL. The data are combined in analysis what the last revision to be done.

\section{Data Collecting Instrument}

Instrument is a tool to get the data in the research. In relation to the objectives of the study, the researcher employed questionnaires, they are the questionnaire of readability and implementability of the product. The purpose of those questionnaires is to know the students' response of material development.

The researcher uses experts' opinion in order to revise the material of Problem Based Learning (PBL). There are two kinds of questionnaires namely readability and implementability. The questionnaire of 
readability is used to measure the sightings and attractiveness of the material itself. In addition, the questionnaire of implementability is applied to measure the level of the material is too difficult, too easy or mediocrity and whether the material is suitable with standard competence or not.

From the explanation above the researcher uses triangulation like experts' opinion or expert judgment, readability instrument, and implementability instrument.

\section{Instrument of Product Readability}

This instrument is used to collect the data of the understanding of respondent toward material content and Problem Based Learning (PBL) approach principal. Sitepu (2010) has designed some indicators to measure readability namely:

\section{1) Font Size}

It is related to size of the alphabet or words. If the font size are big or small, the students cannot catch the materials easily.

\section{2) Word Choice}

It means that the researcher choose the easy words to make the students understand about the message of the content of the text.

\section{3) Content and Message}

The researcher has designed the text and the questions for the students on material development. The researcher has adjusted with students' information of material product.

4) Instruction based PBL

Every material has instructions based on PBL. The students get information easily about how the material is.
5) Lay Out

The illustrations are related to the attractiveness of the material product. The content of this indicators are pictures, writing form, color, and the message of the material.

\section{Instrument of Product Implementability}

This instrument is used to collect the data about material development based on Problem Based Learning (PBL) in field testing. There are some indicators in product implementability namely:

1) Instruction

It means that the instructions are clearly and orderly, so the students easy to understand about the instruction.

2) Exploring students knowledge ability The students use their knowledge to explore the answer of the question in their group.

3) Opinion on evaluation based PBL The students will give a comment and suggestion about the material product.

\section{Analyzing Questionnaires of Product Readability}

Readability instrument is questionnaire one and it is used to measure the sightings of the material itself. Then, the researcher also use some to count the frequency of questionnaire to see the data. In this readability the researcher use seven questions to check the readability of the material product. The questions are related to the indicator above like font size, word choice, lay out, content, message, and instruction based on Problem Based Learning. 


\section{Analyzing Questionnaires of Product Implementability}

Implementability instrument is in questionnaire two. The purpose of this analysis is to know how far this product can be applied. It is also used to revise the product in order to get better product. This questionnaire is used by the researcher to get the comment from the students about the product to repair, revise, and develop the product. In this case the students give some comment for the content of material. And the researcher uses this questionnaire to get responds from the students.

\section{Research Method: Stage 2}

\section{Product Design}

This prototype is designed based on Problem Based Learning especially for speaking skill. It is gotten by self evaluation, expert review and one to one, small group and field test. By doing the small group step, the researcher gets the result of it and it is revised for the second product. It finally becomes the third prototype.

\section{Research Subject}

The subject of this research is the student of State Junior High School 6 Metro at eighth grade. The respondents are gotten by simple random sampling. It is chosen without using specific criterion. It is necessary to do field test. The researcher uses one class as the respondents. Using criteria based competences that develop in learning activities at eighth grade and the students are around twenty five students. The students get the second prototype (the material product based revision from small group) after that they get questionnaires.

\section{Types of Data}

The researcher uses the type of data questionnaire of product readability and implementability. Data of the result score of material product is obtained collectively as the basis to revise the product and develop speaking material based on Problem Based Learning especially in descriptive and recount text.

\section{Data Collecting Instrument}

In this part of field test, the researcher will use questionnaire of product readability and implementability like in one-to-one and small group step. The researcher employs questionnaires. The questionnaire is to know students' response of material development. The researcher will get data based on the questionnaires given. There are two kinds of questionnaires; the questionnaire of product readability and implementability.

\section{Data Analysis Technique}

To get the data, the researcher uses two main instruments they are analyzing of readability and analyzing of implementability questionnaire. Based on the result of scoring questionnaire above, it needs to know readability and implementability of the product based on Problem Based Learning (PBL).

\section{RESULTS}

\section{Result of Product Designing}

English learning material based on Problem Based Learning (PBL) is a product design which is developed for speaking skill. Product design of this research is developed by using PBL, which are the students find the problem related to their environment and solve the problem, 
then the students can explore their speaking skill easily.

The material product is designed in some steps. The first step is selfevaluation, the researcher analyzes the learning objectives as basic to develop English learning material for speaking skill. In this step the researcher found some grammatical error.

The material product is reviewed by expert and one-to-one. The experts or panelists consist of two experts in English instruction studies. The first expert is $\mathrm{Mr}$. Refai, M.Pd., and the second expert is Mr. Syaifudin Latif, M.Pd. The first expert suggested using terminology on definition of the texts. Meanwhile the second expert suggested changing the cover of the product in each text. From one-to-one step is gotten information that the students have accepted from the material product, but it needs some simple explanation and it can be more understood for them.

Based on the statement above, it can conclude that the researcher revised the material product by correcting the grammatical error, using a terminology of the texts to be simple and easy to follow and change the cover of the product.

\section{Result of the First Product Testing}

This product testing is called small group testing that includes six respondents. The respondents ask to finish and comment English learning material product based on PBL approach. After getting the material product, the respondents get readability questionnaire. It includes five aspects such as font size, word choice, layout, instruction, content and message. That aspect as the indicator on the questionnaire is used to get some suggestions from the implementability instrument. The result of those instruments is used as the basis of revision.

After the respondents filled the questionnaire of readability, the researcher gets the result. The result of the indicator is very high score category, but the word choice has low score. It means that the word choice needs to be revised. The following chart shows the result of questionnaire of product readability per item (small group).

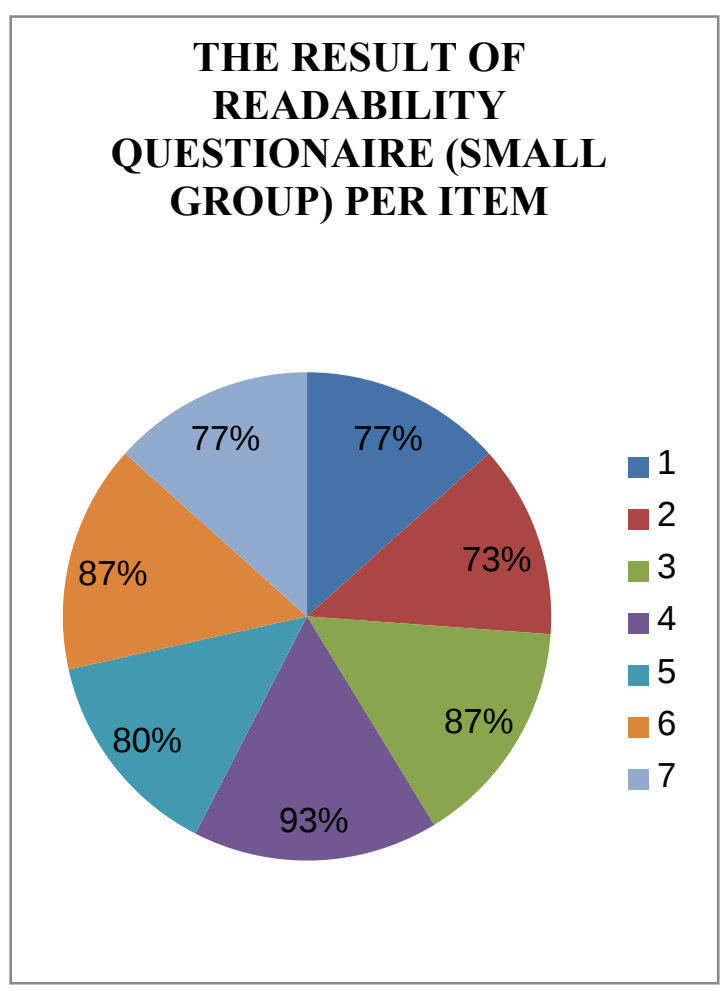

Based on the result of the explanation above, it can be concluded that the material product are readable for the students in some aspects. However, the researcher needs to revise it in word choice of the material product, because it has low score. The result of readability questionnaire per indicator (small group) is given in the following chart. 


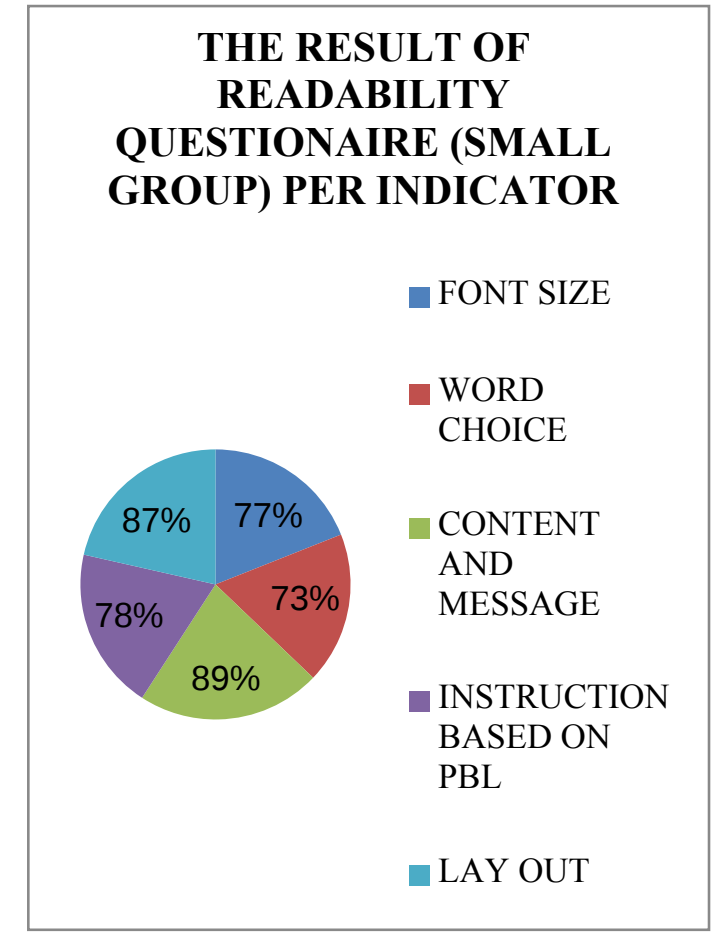

Based on the chart above, the result of product readability per indicators are, $77 \%$ for font size, $73 \%$ for word choice, $89 \%$ for content and message, $78 \%$ for instruction, and $87 \%$ for lay out. The highest score was $89 \%$ for content and message, and the lowest score was $73 \%$ for word choice. It means that the students have a good response to the material product.

On the other hand, the result of product implementability is good enough, but some of the respondents feel difficult or confuse about the meaning of some words.

\section{Revision on the First Product Testing}

According to the result of product testing of English learning material for speaking skill based on PBL, there is an indicator that needs to be revised. The indicator of word choice has the lowest score, so the researcher needs to revise it. The students get difficulties to know the meaning of the words easily because the word choice on the material product before is seldom used by the students. The researcher revised the word choice on the material product in simply explanation and uses the words which the students usually use in daily life.

\section{Result of the Second Product Testing}

This second product testing is called field test, the researcher chooses twenty five students in eighth grade as respondents. After getting the material product, the students get readability and implementability questionnaire. The result of all the components of readability questionnaire is high score categories. The result of readability questionnaire per item (field test) is given in the following chart.

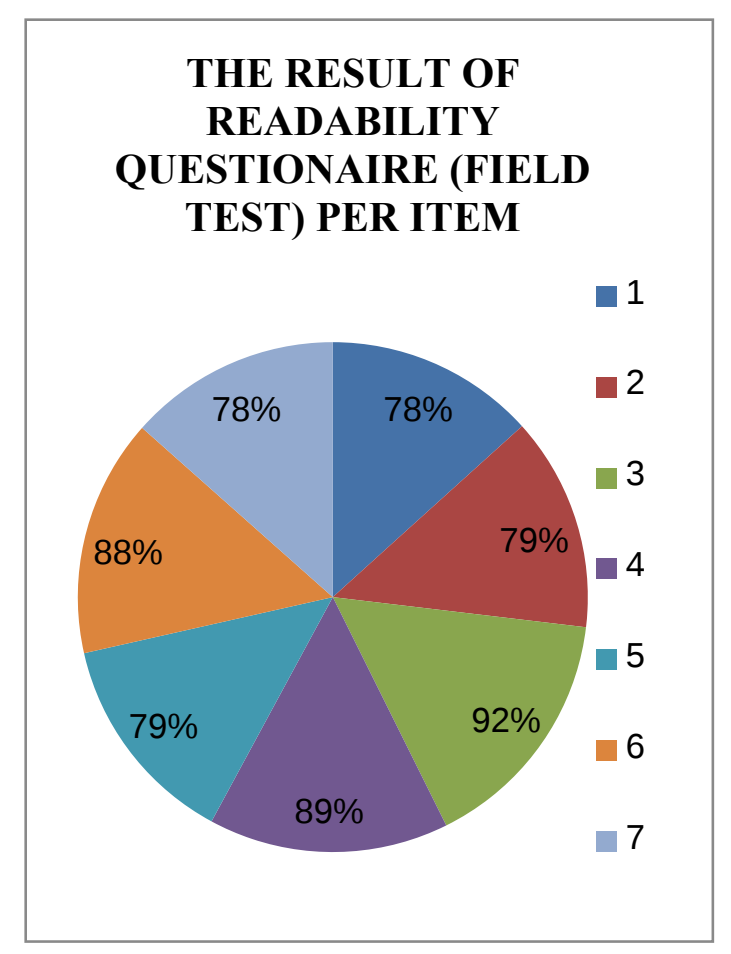

Based on the chart above, the result of readability questionnaire per item is high. It means that the student have good response to the material product. They interested to do activity on the material product to increase their skill in speaking. The result means that the material product can be used for the students of eighth grade. The result of readability 
questionnaire per indicator (field test) is given in the following chart.

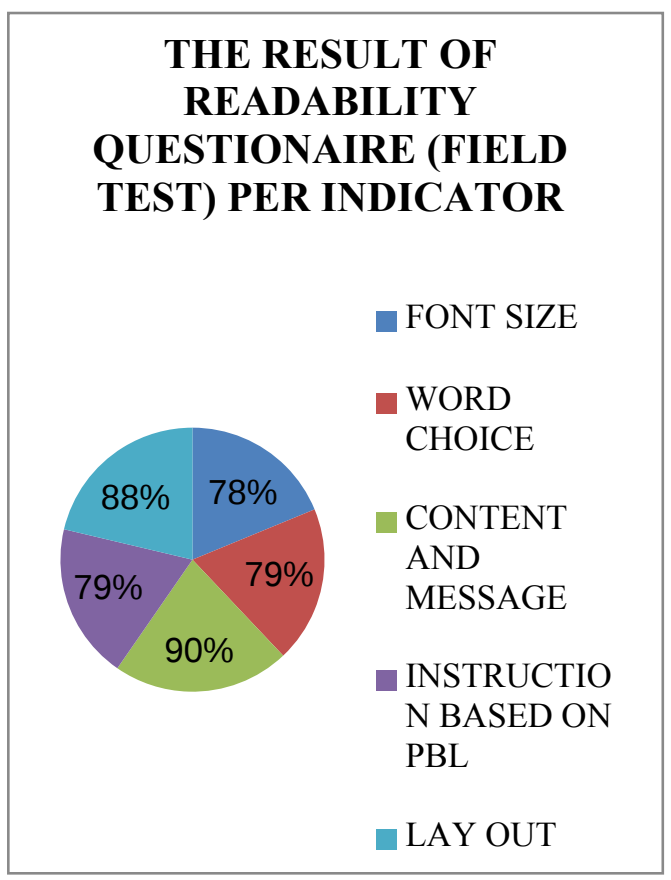

Based on the chart above, the result of product readability questionnaire per indicator is, $78 \%$ for font size, $79 \%$ for word choice, $90 \%$ for content and message, and $79 \%$ for instruction, and $88 \%$ for layout. Every indicator has high score. The material product does not need the revision and can be use for the student of eighth grade.

The result of implementability questionnaire can be concluded that the respondents are interested to the material product.

\section{Revision of the Second Product Testing}

Based on the result of product testing of the material based on PBL, the researcher revised the material product in all aspect on indicator which has low score, although all score of indicator in high categories. The researcher revised the material by adding the explanation about descriptive and recount text and made word choice on the material product in simply explanation and used the words which the students usually use in daily life.
On the other hand, the result of implementation of the material product did not get some troubles. The respondents have good responses, so the researcher does not revise for implementability.

\section{Refinement of the Second Product}

Developing English learning material for speaking skill based on PBL is a product that develops students' speaking skill. Based on many revisions in some step of testing product, English speaking material was made as perfect as possible. Start from self evaluation, the researcher found the weakness on the material product. There is some grammatical error on the material product.

In expert review, the first expert review suggested using terminology on definition of the texts. And the second expert suggested changing the cover of the material product in each text. From one-toone step, both of the students accept the material product.

In small group step, the researcher got good response from the respondents. They show their interest to the material product because the material product related to their daily life context, although they got some difficulties in translating the words. The word choice in this step needs to be revised.

In field test step, the researcher applied the material product in one class. The result of the questionnaire shows that the students are interested to the material product and they have good responses.

Based on the explanation above, the refine product includes content and word choice. The content is adding the terminology on definition of the texts, correcting the grammatical errors, and changing the cover of the material product in each text. Besides made some simple explanation and it can be more understood for them. 


\section{Overall Finding}

Referring to the finding of readability instrument between small group and field test, the result of readability in small group stated the respondents give good response to the material product. The results of readability questionnaire in small group per indicators are $77 \%$ for font size, $73 \%$ for word choice, $89 \%$ for content and message, $78 \%$ for instruction based on PBL, and $87 \%$ for lay out. The highest score was $89 \%$ for content and message and the lowest score was $73 \%$ for word choice. Some students got difficulties about the meaning of some words.

On the other hand, the result of readability in field test has high score. The result are $78 \%$ for font size, $79 \%$ for word choice, $90 \%$ for content and message, $79 \%$ for instruction based on PBL, and $88 \%$ for lay out.

Based on the statement above, it can conclude that the students show their interest and can explore their skill through English learning material product for speaking skill based on problem based learning. According to Savin-Baden (2004: $3)$ through this exploration students are expected to examine gaps in their own knowledge and skills in order to decide what information they need to acquire in order to resolve or manage the problem situation. The material product is readable for the students, so the students get the point easily and become active by doing some activities on the material product that related to their daily life context and they are given the problem on the material product to explore their speaking skill.

The result of the explanation above is English learning material for speaking skill based on PBL is success and it can be applied in eighth grade of Junior High School.

\section{Discussion of Final Product}

English learning material product for speaking skill based on PBL is made to serve the context related to the content completely to understand the information, so it can explore the students' knowledge by some activities. By doing the activity, the students can learn how to explore their speaking skill easily.

Based on the questionnaire given for the eighth grade students' of SMP N 6 Metro, English learning material for speaking skill based on PBL was made as perfect as possible and serve the complete material about speaking skill. It is to explore their speaking skill easily, to understand the material. The material product is readable for the students, so the students get the point easily and become active by doing some activities on the material product to explore their speaking skill.

\section{CONCLUSION AND SUGGESTION}

\section{Conclusion}

This research study has main objective to develop practical English speaking materials by using Problem Based Learning (PBL). In this chapter, research findings are summarized and the suggestions are proposed. Referring to the findings of this study, the researcher revised the material product above:

1) English learning material for speaking skill based on PBL was made as perfect as possible to get the students understanding. From one-to-one step is gotten information that the students have accepted the material product, but it needs some simple explanation and it can be more understood for the students. 
2) In experts review, the experts suggest to add the terminology on definition of the texts, and change the cover of the material product in each text.

3) In small group step, the respondents showed good responses and they interested to the material product, but they got some difficulties in translating the words on the material product because the words are seldom used by the students.

4) In field test step, the response of the material product is high. The researcher revised the word choice on the material product in simply explanation and used the words which the students usually use in daily life. In short, the material product is not only interesting but also it can improve the students' speaking skill.

\section{Suggestion}

This study is significant for the attempt to develop English learning material for speaking skill based on Problem Based Learning (PBL) for eighth grade students of Junior High School at the first semester. There are some suggestions for the next implementation of English learning materials which can be proposed to English teachers who teach in Junior High School. Referring to the findings of this study, the researcher recommends:

1) Problem Based Learning approach can be one way to make an English learning material for speaking skill and it is interesting for learning process.

2) The students who use this material can increase their skill in speaking. Some activities on the material product can help the students to explore their knowledge and can produce active learning.
3) The teachers who use this material product can improve their teaching style to get students' interest in learning process. 


\section{REFERENCES}

Boud, D., and G. Feletti (Eds.). (1991).

The Challenge of Problem-Based

Learning. New York: St. Martin's

Press.

Brown. (2001). Teaching by Principles:

An Interactive Approach to

Language Pedagogy. Longman.

USA.

Bull. (2003). Oxford Learner's Pocket

Dictionary: Fourth Edition.

Oxford University Press.

Dudley-Evans and John, St. (1998).

Developments in English for

Specific Purpose.

CambridgUniversity Press.

Hornby, A.S.1995. Oxford Advanced

Learner's Dictionary. Oxford:

Oxford University Press.

Margetson, D. (2001). Can all education be problem-based: Can it afford not to be? Problem-Based Learning Forum, Hongkong Centre for Problem-based Learning.

Savin-Baden, M., \& Howell Major, C. (2004). Foundations of problembased learning. Birkshire, England: The Society for Research into Higher Education \& Open University Press. 
Sholihin, Ubaidillah Ibnu. (2014).

Definition of Speaking Skill.

Retrieved from

http://rujukanskripsi.blogspot.com

/2013/06/definition-of-speaking-

skill.html on January 15, 2014.

Sitepu. (2010). Keterbacaan Keterbacaan

(Online), (http:// karya ilmiah. um.

ac.id /index.php/ disertasi / article/

view /8029, diakses 9 April 2012).

Tessmer, Martin. (1993). Planning and

Conducting Formative Evaluation.

London: Kogan Page Limited.

Tomlinson, Brian. (1998). Materials

Development in Language

Teaching. Cambridge

University Press 